\title{
THE EFFECT OF PREMATING STRESS ON THE ONSET OF OESTRUS AND ON OVULATION RATE IN SCOTTISH BLACKFACE EWES
}

\author{
J. M. DONEY, R. G. GUNN AND J. G. GRIFFITHS \\ Hill Farming Research Organisation, \\ Bush Estate, Penicuik, Midlothian
}

(Received 22nd May 1973)

In a previous experiment, Scottish Blackface ewes maintained in a stressful situation for the duration of a full oestrous cycle before mating had a lower ovulation rate than similar ewes maintained in a non-stressful environment to which they were accustomed (Griffiths, Gunn \& Doney, 1970). The nonstressful environment was provided by group pens in a well ventilated but sheltered sheephouse and the stressful environment was created by similar pens on an exposed out-of-doors site with additional heavy rainfall simulated by an overhead spray system. The present experiment was carried out to investigate the effect on ovulation rate of shorter duration stress and of previous management.

Experimental ewes were taken from two sources. Home-bred adult ewes, of the Scottish Blackface breed on the research station at Sourhope, Roxburghshire, were already accustomed to the additional handling, indoor housing, group feeding, and which is involved in experimental treatment, whereas purchased ewes of a similar strain and type came from a commercial hill farm in the same region and were not accustomed to disturbance or confinement. When purchased in late September, there was no obvious difference in size or weight at comparable condition between ewes from the two sources. All ewes were run as a single flock but were separated into a number of paddocks and differentially group-fed to achieve and maintain a uniform, moderate body condition (Grade 2.5; Russel, Doney \& Gunn, 1969). In mid-October, the ewes were transferred to group pens in the sheephouse and oestrus was synchronized by means of progestagen sponges. On Day 1 of the post-synchronous cycle, ewes were allocated at random to the following groups: (1) unstressed control (UU-twenty-three ewes), which remained in the sheephouse until after mating; (2) stress in early cycle (SU-fifty ewes), tranferred to stress environment for a 5 - or 6-day period ( 1 to 5 or 6 to 11 ); (3) stress in late cycle (US-thirty ewes), transferred from Day 12 till mating; (4) continuous stress (SS - twenty-four ewes), transferred from Day 1 till mating.

The stress environment was provided by outdoor group pens with a minimum of $6 \mathrm{hr}$ daily wetting as in the previous experiment (Griffiths et al., 1970). Fertile rams were introduced on Day 12 and matings were recorded twice daily. Eighteen rams were used and these were moved round the mating groups daily. All ewes were retained in the final treatment environment until 
they were mated and were then killed within 3 days for examination of the ovaries.

Considerable variation in cycle length was found. A cycle length between 13 and 21 days was classified as normal (expected mean, 16.5 \pm 2 ). Onset of oestrus between 26 and 36 days after the first post-synchronous oestrus was classified as delayed. The numbers of ewes with normal or delayed oestrus are shown in Table 1 according to source and treatment. For this purpose, groups were combined according to the treatment during the last period only. Groups

Table 1. The effect of stress in the final period of the oestrous cycle and of source of sheep on the number of ewes with normal or delayed onset of oestrus

\begin{tabular}{l|c|c|c|c}
\hline \multirow{2}{*}{} & \multicolumn{2}{|c|}{ Home-bred ewes } & \multicolumn{2}{c}{ Purchased ewes } \\
\cline { 2 - 5 } & \multicolumn{2}{|c|}{ Onset of oestrus } & \multicolumn{2}{c}{ Onset of oestrus } \\
\cline { 2 - 5 } & Normal & Delayed & Normal & Delayed \\
\hline Combined stress groups (-S) & 12 & 10 & 14 & 18 \\
Combined unstressed groups (-U) & 25 & 6 & 33 & 9 \\
\hline
\end{tabular}

US and SS are described as the combined stress group in relation to this last period (-S) and Groups UU and SU as the combined unstressed group (-U). Irrespective of source, both US and SS had a higher incidence of delayed oestrus $(48.2 \%$ and $56 \%$, respectively) than did UU $(17.4 \%)$ and SU $(22 \%)$. When combined as shown, the difference was highly significant $(P<0.01)$. The effect of source of ewe on delayed oestrus was not significant although there was generally less delay in the home-bred group. Only one ewe in the home-bred group kept permanently in the unstressed environment had an abnormal cycle length.

The category described as 'delayed oestrus' could include silent oestrus and failure to ovulate. Definite indications of recently regressed CL were found in many cases whereas, in others, no such CL could be identified by visual inspection and dissection. As all ewes were mated by Day 38, it would appear that continued treatment had no effect beyond the first expected oestrus.

Treatments imposed on Day 12 were to be continued until after mating on the assumption that this would occur between Days 16 and 17 in most ewes. Because of the delay, some ewes nominated to group SU had been at least 15 days in the control environment before mating and were reclassified as UU. Similarly, a large number of ewes nominated as US had to be reclassified as SS. Analysis of ovulation rate in respect of source and treatment was therefore carried out in two ways. Firstly, the analysis was restricted to those ewes which were mated within the expected oestrous period and which corresponded to the treatments as originally nominated. Secondly, since it is possible that these ewes may have been a biased sample of the least susceptible individuals, the analysis was repeated on all ewes, using the number of CL present at the time of mating. Both preliminary analyses gave similar results and further analysis disclosed no differences between UU and SU or between SS and US groups. 
The final analysis of the data, as shown in Table 2, was made on the results for all ewes according to source and treatment during the final phase (-U or $-\mathrm{S})$.

Irrespective of source, the ovulation rate of $132 \%$ in -U ewes was significantly higher $(P<0.01)$ than in $-S$ ewes $(111 \%)$. Similarly, the ovulation rate in home-bred ewes, irrespective of treatment $(138 \%)$, was significantly higher $(P<0.01)$ than that of purchased ewes $(113 \%)$. As the interaction $\chi^{2}$ was high, the effect of treatment was analysed within each source. In the home-bred

Table 2. The effect of stress and source of sheep on ovulation rate, expressed as number of ewes with single or multiple ovulations

\begin{tabular}{l|c|c|c|c|c|c}
\hline & \multicolumn{3}{|c|}{ Home-bred ewes } & \multicolumn{3}{c}{ Purchased ewes } \\
\cline { 2 - 7 } & $\begin{array}{c}\text { Single } \\
\text { ovulation }\end{array}$ & $\begin{array}{c}\text { Multiple } \\
\text { ovulation }\end{array}$ & $\begin{array}{c}\text { Ovulation } \\
\text { rate (\%) }\end{array}$ & $\begin{array}{c}\text { Single } \\
\text { ovulation }\end{array}$ & $\begin{array}{c}\text { Multiple } \\
\text { ovulation }\end{array}$ & $\begin{array}{c}\text { Ovulation } \\
\text { rate (\%) }\end{array}$ \\
\hline $\begin{array}{c}\text { Combined stress } \\
\text { groups (-S) } \\
\begin{array}{c}\text { Combined unstressed } \\
\text { groups (-U) }\end{array}\end{array}$ & 19 & 3 & 114 & 29 & 3 & 109 \\
\hline
\end{tabular}

group, the ovulation rate of stressed ewes $(114 \%)$ was significantly lower $(P<0.001)$ than that of the unstressed ewes $(156 \%)$ whereas the difference was not significant in the purchased group (109\% and $117 \%$, respectively). Similarly, within treatment groups, the homebred ewes had a significantly $(P<0.01)$ higher ovulation rate than purchased ewes when unstressed but the difference was not significant when both were in the stress environment before mating.

The results of this experiment are not conclusive because of relatively small numbers and interactions. They do suggest, however, that, although ovulation rate in this breed has been shown to be directly associated with variation in body condition (Gunn, Doney \& Russel, 1969), it may also be influenced significantly by environmental factors which can, loosely, be described as 'stressful'. Environmental stress may also be of critical importance when imposed during a relatively short period towards the end of the oestrous cycle. This covers the period of CL regression (Thorburn, Bassett \& Smith, 1969), of maturation of the final wave of follicular growth (Smeaton \& Robertson, 1971) and preovulatory changes in ovarian and pituitary hormone release (Cumming, Brown, Blockey \& Goding, 1971). Environmental stress over this period appears to have had two distinct effects; there was delay, or suppression, of overt oestrus and depression of the mean ovulation rate.

The differential response of ewes from the two sources cannot be explained from these results. There were no differences in size or weight or in the apparent effects of early growth which could cause differences in ovulatory response (R. G. Gunn and J. M. Doney, unpublished observations). It is possible that the difference lay in the subjective description of stress and unstressed situations. These descriptions may have been reasonably justified in the case of the homebred ewes but both environments were completely unfamiliar for the purchased ewes. 
The authors wish to acknowledge the assistance of Mr J. Senior and Mr W. F. Smith.

\section{REFERENCES}

Cumming, I. A., Brown, J. M., Blockey, M. A. B. \& Goding, J. R. (1971) Regulation of the oestrous cycle in the ewe. $\mathcal{F}$. Reprod. Fert. 24, 148 (Abstr.).

Griffiths, J. G., Gunn, R. G. \& Doney, J. M. (1970) Fertility in Scottish Blackface ewes as influenced by climatic stress. F. agric. Sci., Camb. 75, 485.

Gunn, R. G., Doney, J. M. \& Russel, A. J. F. (1969) Fertility in Scottish Blackface ewes as influenced by nutrition and body condition at mating. F. agric. Sci., Camb. 73, 289.

Russel, A. J. F., Doney, J. M. \& Gunn, R. G. (1969) Subjective assessment of body fat in live sheep. 7. agric. Sci., Camb. 72, 451.

Smeaton, T. C. \& Robertson, H. A. (1971) Studies on the growth and atresia of Graafian follicles in the ovary of the sheep. F. Reprod. Fert. 25, 243.

Thorburn, G. D., Bassett, J. M. \& SMith, I. D. (1969) Progesterone concentration in the peripheral plasma of sheep during the oestrous cycle. $\mathcal{F}$. Endocr. 45, 459. 